Volume 11, Nomor 2, November 2019, pp 218-229 Copyright (C) 2017 Jurnal Akuntansi Maranatha, Program Studi Akuntansi, Fakultas Ekonomi, Universitas Kristen Maranatha. ISSN 2085-8698 | e-ISSN 2598-4977. http://journal.maranatha.edu

\title{
Board Size, Ownership Diffusion, Gender Diversity, Media Exposure, dan Pengungkapan Corporate Social Responsibility (Studi Kasus pada Perusahaan Indeks SRI-KEHATI yang terdaftar di Bursa Efek Indonesia Periode 2013-2017)
}

\author{
Lusia Revika Septianingsih \\ Fakultas Ekonomi dan Bisnis Program Studi Akuntansi-Universitas Telkom \\ (Jl. Telekomunikasi Terusan Buah Batu, Dayeuh Kolot, Bandung) \\ lusiarevika@gmail.com \\ Muhamad Muslih \\ Fakultas Ekonomi dan Bisnis Program Studi Akuntansi-Universitas Telkom \\ (Jl. Telekomunikasi Terusan Buah Batu, Dayeuh Kolot, Bandung) \\ muslih.moeztea@gmail.com
}

\begin{abstract}
This study aims to analyze the effect of board size, ownership diffusion, gender diversity, and media exposure to CSR disclosure. The population in this study is the SRI-KEHATI index company listed on the Indonesia Stock Exchange during 2013-2017. The total sample obtained using purposive sampling technique is as many as 50 samples, consisting of 10 companies for 5 years. The analysis technique used in this study is panel data regression analysis.The results of the study show that partially, the board size affects the disclosure of corporate social responsibility and results in a negative direction. Meanwhile, ownership diffusion, gender diversity, and media exposure have no effect on disclosure of corporate social responsibility.
\end{abstract}

Keywords: Board Size, Corporate Social Responsibility Disclosure (CSRD), Gender Diversity, Media Exposure, and Ownership Diffusion. 


\section{Pendahuluan}

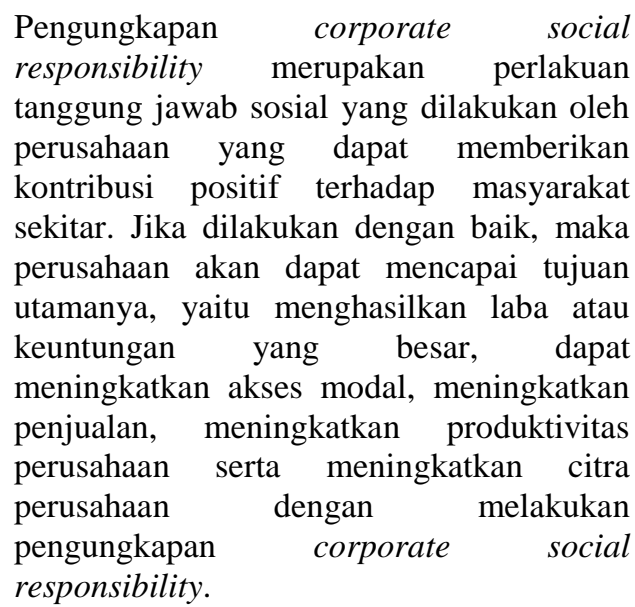

Pemerintah Indonesia menyadari akan pentingnya tanggung jawab sosial yang harus diterapkan oleh perusahaan, maka dari itu dibuatlah peraturan mengenai pelaksanaan tanggung jawab sosial perusahaan serta lingkungan, yaitu UndangUndang No. 40 tahun 2007 Pasal 74 ayat 1 (Hadi, 2011). Undang-Undang No. 40 tahun 2007 berisi: "Perseroan yang menjalankan kegiatan usahanya di bidang dan/atau berkaitan dengan sumber daya alam wajib melaksanakan tanggung jawab sosial dan lingkungan".

Global Reporting Initiative (GRI)
merupakan sebuah program dari
Perserikatan Bangsa-Bangsa (PBB) pada
tahun 2000 yang dibuat sebagai pedoman
mengenai Sustainability Reporting yang
dapat digunakan oleh perusahaan untuk
mengungkapkan tanggung jawab sosial
perusahaan 4 (corporate
responsibility). Tocial
pengungkapan standar yang berbeda, yaitu
pengungkapan standar umum dan
pengungkapan standar khusus.
Pengungkapan standar umum, meliputi tujuh aspek, yaitu: (1) strategi dan analisis; (2) profil organisasi; (3) aspek material dan boundary teridentifikasi; (4) hubungan dengan pemangku kepentingan; (5) profil laporan; (6) tata kelola; (7) etika dan integritas. Sedangkan, pengungkapan standar khusus terdiri dari tiga kategori, yaitu: (1) ekonomi; (2) lingkungan; (3) sosial (GRI, 2013).

Pengungkapan CSR perusahaan indeks SRI-KEHATI diindikasikan mengalami penurunan pada tahun 2015 sampai dengan 2017. Pada tahun 2015, pengungkapan CSR turun menjadi $41,61 \%$ dari tahun sebelumnya yaitu $46,17 \%$. Pada tahun 2016, rata-rata pengungkapan CSR turun menjadi $38,05 \%$, kemudian pada tahun 2017 semakin menurun menjadi $33,76 \%$. Penurunan ini terjadi karena kurangnya kepedulian perusahaan terhadap lingkungan sekitar, sehingga pengungkapan corporate social responsibility perusahaan juga mengalami penurunan. Perusahaan yang masuk ke dalam indeks SRI-KEHATI merupakan perusahaan yang menyeimbangkan antara kepentingan bisnis dengan kepedulian lingkungan sekitar perusahaan. Seharusnya perusahaan meningkatkan kegiatan-kegiatan yang berkaitan dengan tanggung jawab sosial serta pengungkapannya, sehingga tahuntahun berikutnya pengungkapan corporate social responsibility dapat terus meningkat.

Terdapat banyak faktor yang diduga mempunyai pengaruh terhadap pengungkapan corporate social responsibility diantaranya board size, ownership diffusion, gender diversity dan media exposure. Variabel tersebut memang sudah ada dalam beberapa penelitian tetapi masih terdapat inkonsistensi.

Faktor pertama yaitu board size atau ukuran dewan komisaris adalah jumlah dewan komisaris dalam suatu perusahaan (Restu et al, 2017). Semakin banyak jumlah dewan komisaris dalam suatu perusahaan, maka akan semakin mudah dalam mengendalikan CEO serta pengawasan dapat dilakukan dengan efektif (Assegaf et $a l, 2012)$.Berdasarkan hasil penelitian yang dilakukan oleh Restu et al (2017) menyatakan bahwa ukuran dewan komisaris (board size) berpengaruh positif terhadap pengungkapan CSR.Namun bertentangan dengan hasil penelitian Assegaf et al (2012) 
yang menyatakan bahwa pengaruh board size terhadap Islamic Social Responsibility Disclosure tidak signifikan.

Faktor kedua adalah ownership diffusion (kepemilikan saham publik). Menurut Rifqiyah (2016) kepemilikan saham publik (ownership diffusion) merupakan proporsi kepemilikan saham yang dimliki oleh publik yang tidak memiliki hubungan dengan manajemen perusahaan terhadap saham perusahaan di bawah 5\%. Perusahaan yang memiliki ownership diffusion tinggi maka akan lebih banyak mendapatkan dorongan dalam pengungkapan corporate social responsibility. Berdasarkan hasil penelitian Umar (2015) ownership diffusion berpengaruh positif signifikan terhadap pengungkapan CSR. Namun, bertentangan dengan hasil penelitian Assegaf et al (2012) yang menyatakan bahwa ownership diffusion tidak berpengaruh terhadap pengungkapan tanggung jawab sosial Islam.

Faktor ketiga yaitu gender diversity. Saat ini, berbagai perusahaan besar di Indonesia memberikan kesempatan terhadap setiap individu untuk menempati berbagai posisi penting perusahaan, hal tersebut terlihat dari adanya wanita di jajaran dewan komisaris dan direksi.Secara tradisional, budaya serta sosial, wanita dan laki-laki sudah berbeda (Liao, L, dan Q. Tang, 2015). Pada umumnya, wanita modern sangat sadar akan pentingnya pendidikan yang akan membuat mereka mampu menjadi seorang yang profesional, sehingga berhasil menempati jajaran penting di perusahaan. Selain itu jika dilihat dari kepribadian, gaya bekerja, dan gaya berkomunikasi antara wanita dan laki-laki sudah berbeda. Wanita terlihat lebih rajin, serta berkomitmen. Keterlibatan wanita secara aktif dalam jajaran dewan dapat memberikan kontribusi dalam penentuan tujuan serta pengungkapan tanggung jawab sosial perusahaan (corporate social responsibility disclosure). Berdasarkan hasil penelitian Hadya dan Susanto (2018) keberagaman gender mempunyai pengaruh positif terhadap pengungkapan CSR. Hasil penelitian tersebut bertentangan dengan penelitian yang dilakukan oleh Kahreh et al (2014) yang menyimpulkan bahwa gender differences tidak berpengaruh terhadap corporate social responsibility.

Faktor lainnya adalah media exposure. Peran media massa dalam lingkungan perusahaan sangat penting dalam rangka membentuk opini masyarakat terhadap suatu aktivitas perusahaan. Pengungkapan tanggung jawab sosial perusahaan (corporate social responsibility disclosure) dapat dilakukan melalui berbagai media, seperti media televisi, koran serta media internet (website perusahaan). Media internet (website) adalah media yang sangat efektif untuk mendukung aktivitas operasi suatu perusahaan, karena saat ini masyarakat lebih cenderung menggunakan media internet untuk memperoleh informasi daripada media televisi serta media cetak. Berdasarkan penelitian yang dilakukan oleh Kristi (2012) menunjukkan bahwa media exposure berpengaruh positif terhadap pengungkapan CSR perusahaan. Namun, penelitian yang dilakukan oleh Nur dan Priantinah (2012) menunjukkan bahwa media exposure tidak berpengaruh terhadap pengungkapan CSR perusahaan.

Penelitian ini bertujuan untuk mengetahui dan menganalisis adanya pengaruh board size, ownership diffusion, gender diversity dan media exposure secara simultan maupun parsial terhadap pengungkapan corporate social responsibility pada perusahaan indeks SRIKEHATI yang terdaftar di Bursa Efek Indonesia periode 2013-2017.

Hasil penelitian ini dapat memberikan pandangan serta masukan bagi masyarakat dalam menikmati kegiatan CSR yang dilakukan oleh perusahaan. Selain itu, hasil penelitian ini diharapkan dapat menjadi masukan bagi perusahaan untuk meningkatkan pengungkapan CSR. 


\section{Kerangka Teoritis dan Hipotesis}

\section{Pengungkapan CSR}

Menurut Abubakar et al (2018) pengungkapan corporate social responsibility adalah komitmen perkembangan ekonomi yang berkelanjutan dan berkontribusi dengan melihat tanggung jawab sosial perusahaan terhadap stakeholder serta melihat keseimbangan di antara prospek ekonomi, sosial, serta lingkungan. Menurut GRI (2013), terdapat kriteria yang harus diterapkan oleh organisasi untuk menyusun laporan keberlanjutan sesuai dengan pedoman. Kriteria tersebut mencakup dua opsi, yaitu: opsi inti dan opsi komprehensif. Menurut Wulolo et al (2017) rumus pengukuran pengungkapan corporate social responsibility (CSRDi) adalah sebagai berikut:

Dimana:

$$
\text { CSRDi }=\frac{\sum \mathrm{Xyi}}{\mathrm{ni}}
$$

$\mathrm{CSRDi}=$ Indeks pengungkapan corporate social responsibility perusahaan $\mathrm{i}$

$\sum X y i=$ Nilai 1 jika item y diungkapkan, 0 jika item y tidak diungkapkan

ni= Jumlah item untuk perusahaan $\mathrm{i}$, ni $\leq$ 149 item

\section{Board Size}

Menurut Undang-Undang Perseroan Terbatas Nomor 40 Tahun 2007 ayat 6 dalam Agoes dan Ardana (2014) dewan komisaris merupakan organ perseroan yang mempunyai tugas untuk melakukan pengawasan secara umum dan/atau khusus sesuai dengan anggaran dasar serta memberi nasihat kepada direksi. Board size (ukuran dewan komisaris) merupakan jumlah anggota dewan komisaris pada suatu perusahaan(Restu et al 2017).Semakin banyak anggota dewan komisaris maka nilai yang akan diberikan kepada perusahaan dalam memberikan rekomendasi serta diskusi dalam rapat umum akan semakin besar. Selain itu, manajemen akan mendapat tekanan yang cukup besar dari dewan komisaris untuk menyampaikan informasi perusahaan yang lebih baik. Metode pengukuran board size berdasarkan penelitian yang telah dilakukan oleh Restu et al (2017) adalah sebagai berikut :

$$
\mathrm{BS}=\sum \text { anggota dewan komisaris }
$$

\section{Ownership Diffusion}

Kepemilikan saham publik (ownership diffusion) adalah proporsi kepemilikan saham yang dimliki oleh publik atau masyarakat terhadap saham perusahaan. Publik disini merupakan individu atau institusi yang memiliki saham di bawah 5\% $(<5 \%)$ yang berada di luar manajemen dan tidak memiliki hubungan istimewa dengan perusahaan (Rifqiyah, 2016). Perusahaan yang memiliki ownership diffusion yang banyak menggambarkan bahwa perusahaan tersebut memiliki kredibilitas yang tinggi dan dianggap mampu beroperasi terus menerus, sehingga akan mendorong perusahaan untuk mengungkapkan informasi kegiatan sosial yang dilakukan oleh perusahaan (Nur dan Priantinah, 2012). Metode pengukuran ownership diffusion berdasarkan penelitian yang telah dilakukan oleh Pratiwi dan Palupi (2012) adalah sebagai berikut :

$$
\mathrm{OD}=\frac{\text { jumlah kepemilikan saham publik }}{\text { jumlah keseluruhan saham perusahaan }}
$$

\section{Gender Diversity}

Gender diversity merupakan keragaman yang berfokus pada keberadaan anggota dewan komisaris dan direksi wanita suatu perusahaan (Yumna, 2018). Menurut Adams et al (2005) dalam Solikhah (2016) dewan wanita lebih rajin dalam menghadiri rapat dewan dibandingkan dengan dewan pria. Selain itu, kehadiran wanita dalam jajaran dewan akan semakin meningkatkan keberagaman perspektif anggota dewan. Maka dari itu, semakin banyak wanita berada dalam jajaran dewan maka akan meningkatkan proses pengambilan keputusan, meningkatkan efektivitas dewan 
serta wanita memiliki kehadiran atau partisipasi yang lebih baik.Adapun metode pengukuran berdasarkan penelitian Rahindayanti et al (2015) adalah sebagai berikut :

$$
\mathrm{GD}=\frac{\begin{array}{c}
\text { jumlah anggota } \\
\text { dewan komisaris dan direksi perempuan }
\end{array}}{\text { jumlah anggota }} \times 100 \%
$$

\section{Media Exposure}

Menurut Widiastuti et al (2018) media exposure merupakan kejadian atau kegiatan perusahaan yang berdampak pada sosial dan lingkungan yang diliput oleh media atau dipublikasikan oleh media. Pemberitaan media dapat berupa bad news dan juga good news. Menurut Solikhah dan Winarsih (2016) keberadaan pengungkapan media mengenai lingkungan merupakan atribut eksternal perusahaan yang dapat mempengaruhi pandangan masyarakat terhadap komitmen perusahaan mengenai lingkungan sekitarnya. Dengan adanya pengungkapan media dapat meningkatkan citra atau reputasi perusahaan di mata masyarakat. Metode pengukuran media exposure berdasarkan penelitian yang telah dilakukan oleh Tan et al (2016) adalah sebagai berikut :

$$
\mathrm{ME}=\sum \begin{gathered}
\begin{array}{c}
\text { pemberitaan mengenai CSR setiap perusahaan } \\
\text { pada website Koran Bisnis Indonesia } \\
\text { (Kompas dan Republika) }
\end{array} \\
\text { (Kompas }
\end{gathered}
$$

Model Penelitian Dan Pengembangan Hipotesis

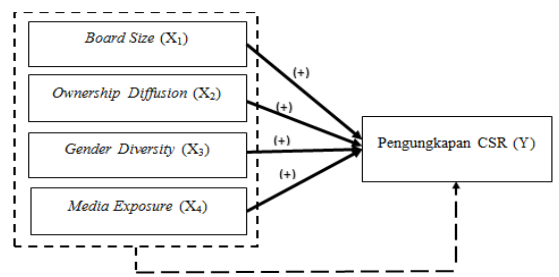

\section{Gambar 1}

\section{Model Penelitian}

$\mathrm{H}_{1}$ : Board Size, Ownership Diffusion, Gender Diversity dan Media Exposure berpengaruh signifikan secara simultan terhadap pengungkapan corporate social

responsibility.

$\mathrm{H}_{2}$ : Board Size berpengaruh positif secara parsial terhadap pengungkapan corporate social responsibility.

$\mathrm{H}_{3}$ : Ownership Diffusion berpengaruh positif secara parsial terhadap pengungkapan corporate social responsibility.

$\mathrm{H}_{4}$ : Gender diversity berpengaruh positif secara parsial terhadap pengungkapan corporate social responsibility.

$\mathrm{H}_{5}$ : Media exposure berpengaruh positif secara parsial terhadap pengungkapan corporate social responsibility.

\section{Metode Penelitian}

\section{Jenis Penelitian}

Metode penelitian yang digunakan adalah kuantitatif, metode dengan pengumpulan data menggunakan instrumen penelitian, analisis data bersifat kuantitatif/statistik untuk menguji hipotesis yang telah ditetapkan (Sugiyono, 2016). Penelitian ini termasuk ke dalam penelitian yang bertujuan deskriptif verifikatif. Penelitian deskriptif merupakan penelitian yang dilakukan untuk mengetahui keberadaan nilai variabel mandiri. Sementara, metode verifikatif adalah penelitian yang dilakukan terhadap populasi atau sampel tertentu untuk menguji hipotesis yang ditetapkan. Tipe penyelidikannya adalah kausal, tipe ini berguna untuk menganalisis hubungan suatu variabel independen terhadap dependen (Sugiyono, 2016).

Jenis data dalam penelitian ini menggunakan data panel. Data panel merupakan gabungan antara data time series dengan cross section (Basuki dan Prawoto, 2016:275).

\section{Populasi dan Sampel}

Populasi dalam penelitian ini adalah perusahaan yang masuk dalam indeks SRI- 
KEHATI dan terdaftar di Bursa Efek Indonesia periode 2013-2017.Sampel yang digunakan dalam penelitian ini adalah purposive sampling, yaitu teknik pengambilan sampel dengan pertimbangan tertentu.

Adapun kriteria atau pertimbangan pengambilan sampel yang digunakan penulis adalah:

1. Perusahaan indeks SRI-KEHATI yang telah terdaftar di Bursa Efek Indonesia periode 2013-2017.

2. Perusahaan yang tergabung secara tidak konsisten dalam indeks SRI-KEHATI periode 2013-2017.

3. Tidak menyajikan laporan tahunan secara konsisten selama periode pengamatan dan terdaftar di Bursa Efek Indonesia periode 2013-2017.

4. Tidak menyajikan laporan keberlanjutan secara konsisten selama periode pengamatan dan terdaftar di Bursa Efek Indonesia periode 2013-2017.

\section{Teknik Pengumpulan Data}

Dalam penelitian ini menggunakan data kuantitatif yang menggunakan data sekunder. Pengumpulan data dilakukan melalui:

1. Dokumentasi

Data sekunder yang digunakan adalah laporan tahunan dan laporan berkelanjutan perusahaan indeks SRIKEHATI yang terdaftar secara konsisten di Bursa Efek Indonesia pada tahun 2013-2017 yang diambil dari website resmi perusahaan serta Bursa Efek Indonesia.

2. Studi Kepustakaan

Studi pustaka dilakukan dengan mempelajari dan membaca jurnal, buku, dan referensi lainnya untuk memperoleh pemahaman mengenai board size, ownership diffusion, gender diversity, media exposure, serta pengungkapan corporate social responsibility.

\section{Hasil Penelitian dan Pembahasan}

\section{Uji Hipotesis}

Berdasakan pengolahan data, maka peneliti menemukan hasil sebagai berikut:

1. Uji Hipotesis 1: Pengaruh Board Size, Ownership Diffusion, Gender Diversity, dan Media Exposure terhadap Pengungkapan Corporate Social Responsibility

\section{Tabel 1}

\begin{tabular}{lllr}
\hline \hline R-squared & 0.470084 & Mean dependent var & 0.410067 \\
Adjusted R-squared & 0.278726 & S.D. dependent var & 0.096234 \\
S.E. of regression & 0.081729 & Akaike info criterion & -1.939314 \\
Sum squared resid & 0.240468 & Schwarz criterion & -1.403947 \\
Log likelihood & 62.48284 & Hannan-Quinn criter. & -1.735443 \\
F-statistic & 2.456562 & Durbin-Watson stat & 1.234775 \\
Prob(F-statistic) & 0.016666 & & \\
\hline \hline
\end{tabular}

Uji hipotesis 1, dapat diketahui hasil signifikansinya sebesar $0.016666<0,05$ maka dapat disimpulkan bahwa $\mathrm{H}_{01}$ ditolak dan $\mathrm{H}_{\mathrm{a} 1}$ diterima yang artinya Board Size (BS), Ownership Diffusion (OD), Gender Diversity (GD), dan Media Exposure (ME) secara simultan berpengaruh signifikan terhadap Pengungkapan Corporate Social Responsibility (CSRD) pada perusahaan indeks SRI-KEHATI yang terdaftar di Bursa Efek Indonesia periode 20132017.

2. Uji Hipotesis 2:Pengaruh Board Size terhadap Pengungkapan Corporate Social Responsibility

Tabel 2

\begin{tabular}{ccccc} 
Variable & Coefficient & Std. Error & t-Statistic & Prob. \\
\hline \hline BS & -0.043534 & 0.017083 & -2.548456 & 0.0152
\end{tabular}

Uji hipotesis 2, peneliti menemukan bahwa nilai probability Board Size (BS) sebesar $0.015<0,05$ maka dapat disimpulkan bahwa $\mathrm{H}_{02}$ ditolak dan $\mathrm{H}_{\mathrm{a} 2}$ diterima sehingga Board Size (BS) secara parsial berpengaruh signifikan terhadap Pengungkapan Corporate Social Responsibility (CSRD). 
3. Uji Hipotesis 3: Pengaruh Ownership Diffusion terhadap Pengungkapan Corporate Social Responsibility

Tabel 3

\begin{tabular}{ccccc} 
Variable & Coefficient & Std. Error & t-Statistic & Prob. \\
\hline \hline OD & -0.000412 & 0.974637 & -0.000423 & 0.999
\end{tabular}

Uji hipotesis 3, nilai probability Ownership Diffusion (OD) sebesar 0.9997> 0,05 maka dapat disimpulkan bahwa $\mathrm{H}_{03}$ diterima dan $\mathrm{H}_{\mathrm{a} 3}$ ditolak sehingga Ownership Diffusion (OD) secara parsial tidak berpengaruh signifikan terhadap Pengungkapan Corporate Social Responsibility (CSRD).

4. Uji Hipotesis 4: Pengaruh Gender Diversity terhadap Pengungkapan Corporate Social Responsibility Tabel 4

\begin{tabular}{crrrr} 
Variable & Coefficient & Std. Error & t-Statistic & Prob \\
\hline \hline GD & -0.002596 & 0.002708 & -0.958402 & 0.344
\end{tabular}

Uji hipotesis 4, nilai probability Gender Diversity (GD) sebesar 0.3443>0,05 maka dapat disimpulkan bahwa $\mathrm{H}_{04}$ diterima dan $\mathrm{H}_{\mathrm{a} 4}$ ditolak sehingga Gender Diversity (GD) secara parsial tidak berpengaruh signifikan terhadap Pengungkapan Corporate Social Responsibility (CSRD).

5. Uji Hipotesis 5: Pengaruh Media Exposure terhadap Pengungkapan Corporate Social Responsibility Tabel 5

\begin{tabular}{ccccc} 
Variable & Coefficient & Std. Error & t-Statistic & Prob \\
\hline \hline ME & -0.005047 & 0.004909 & -1.028039 & $0.31 \mathrm{c}$
\end{tabular} Uji hipotesis 5, nilai probability Media Exposure (ME) sebesar 0.3108>0,05 maka dapat disimpulkan bahwa $\mathrm{H}_{05}$ diterima dan $\mathrm{H}_{\mathrm{a} 5}$ ditolak sehingga Media Exposure (ME) secara parsial tidak berpengaruh signifikan terhadap Pengungkapan Corporate Social Responsibility (CSRD).

\section{Pembahasan}

1. Pengaruh Board Size, Ownership Diffusion, Gender Diversity, dan Media Exposure terhadap Pengungkapan Corporate Social Responsibility

Berdasarkan hasil uji hipotesis 1, nilai probabilitas (F-statistic) adalah sebesar 0.016666 dan nilai probabilitas tersebut $<0,05$ atau tidak melebihi tingkat signifikansi (5\%). Dengan demikian diperoleh kesimpulan bahwa $\mathrm{H}_{0}$ ditolak, yang berarti bahwa variabel Board Size (BS), Ownership Diffusion (OD), Gender Diversity (GD), dan Media Exposure (ME) secara simultan memiliki pengaruh signifikan terhadap Pengungkapan Corporate Social Responsibility (CSRD) pada perusahaan indeks SRI-KEHATI yang terdaftar di Bursa Efek Indonesia periode 20132017.

2. Pengaruh Board Size terhadap Pengungkapan Corporate Social Responsibility

Berdasarkan hasi uji hipotesis 2, menunjukkan bahwa variabel board size (BS) memiliki nilai probabilitas sebesar 0.0152. Hal ini mengindikasikan bahwa nilai Prob. $<0,05$, maka $\mathrm{H}_{01}$ ditolak dan $\mathrm{H}_{\mathrm{a} 1}$ diterima dan memiliki arah negatif dengan nilai koefisien sebesar 0.043534 . Dengan demikian dapat disimpulkan bahwa board size (BS) berpengaruh negatif signifikan terhadap pengungkapan corporate social responsibility (CSRD).

Board size berpengaruh negatif signifikan terhadap pengungkapan corporate social responsibility dapat diartikan dengan semakin kecil jumlah dewan komisaris maka perusahaan akan melakukan pengungkapan corporate social responsibility yang lebih baik dibandingkan dengan dewan komisaris yang berjumlah besar. Menurut Nur dan Priantinah (2012) dengan adanya dewan komisaris yang berjumlah sedikit maka 
akan memiliki efektivitas yang baik terhadap pengawasan manajemen perusahaan. Sedangkan, perusahaan dengan dewan komisaris yang berjumlah besar maka pengawasan yang dilakukan akan kurang efektif karena dominasi anggota dewan komisaris yang mementingkan kepentingan pribadi atau kelompoknya, mengesampingkan sehingga perusahaan

Hasil penelitian ini sejalan dengan yang dilakukan oleh Nur dan Priantinah (2012), Kinanti (2011), dan Hakim (2010) yang menyatakan bahwa board size atau ukuran dewan komisaris berpengaruh negatif signifikan terhadap pengungkapan corporate social responsibility. Namun, penelitian ini tidak sejalan dengan penelitian yang dilakukan oleh Abubakar et al (2018), Restu et al (2017), Solikhah dan Winarsih (2016), Isa dan Muhammad S (2015) yang menyatakan bahwa board size berpengaruh positif signifikan terhadap pengungkapan corporate social responsibility serta Ningrum (2015), Aziz (2014), Fitri (2013) yang menyatakan bahwa board size tidak memiliki pengaruh yang signifikan terhadap pengungkapan corporate social responsibility.

3. Pengaruh Ownership Diffusion terhadap Pengungkapan Corporate Social Responsibility

Berdasarkan hasil uji hipotesis 3, menunjukkan bahwa variabel ownership diffusion (OD) memiliki nilai probabilitas sebesar 0.9997. Hal ini mengindikasikan bahwa nilai Prob. > 0,05, maka $\mathrm{H}_{02}$ diterima dan $\mathrm{H}_{\mathrm{a} 2}$ ditolak. Dengan demikian dapat disimpulkan bahwa ownership diffusion (OD) tidak berpengaruh signifikan terhadap pengungkapan corporate social responsibility (CSRD).

Ownership diffusion tidak berpengaruh signifikan terhadap pengungkapan corporate social responsibility dapat diartikan bahwa tinggi rendahnya ownership diffusion atau kepemilikan saham publik tidak mempengaruhi pengungkapan corporate social responsibility. Menurut Nur dan Priantinah (2012) kemungkinan kepemilikan saham publik pada perusahaan di Indonesia secara umum belum mempedulikan masalah lingkungan dan sosial sebagai isu kritis yang harus secara ekstensif untuk dilakukan pengungkapan dalam laporan tahunan. Menurut Putra (2011) ditolaknya hipotesis kepemilikan saham publik dikarenakan merupakan gabungan dari seluruh saham yang dimiliki masyarakat secara luas di luar institusional, manajerial, pemerintah, maupun asing dan hanya memiliki hak minoritas sebagai stakeholder di dalam suatu entitas, sehingga tidak memiliki pengaruh apapun atau memberikan tekanan terhadap manajemen perusahaan untuk melakukan pengungkapan informasi tanggung jawab sosial perusahaan pada laporan tahunan perusahaan.

Hasil penelitian ini sejalan dengan penelitian yang dilakukan oleh Assegaf et al (2012) Nur dan Priantinah (2012), Putra (2011), Rini dan Hasan (2011) yang menyatakan bahwa ownership diffusion tidak berpengaruh signifikan terhadap pengungkapan corporate social responsibility. Namun penelitian ini tidak sejalan dengan penelitian Erviana et al (2018), Pratiwi dan Palupi (2012) yang menyatakan bahwa ownership diffusion memiliki pengaruh yang positif signifikan terhadap pengungkapan corporate social responsibility.

4. Pengaruh Gender Diversity terhadap Pengungkapan Corporate Social Responsibility

Berdasarkan uji hipotesis 4, menunjukkan bahwa variabel gender diversity (GD) memiliki nilai probabilitas sebesar 0.3443. Hal ini 
menunjukkan bahwa nilai Prob. >0,05, maka $\mathrm{H}_{03}$ diterima dan $\mathrm{H}_{\mathrm{a} 3}$ ditolak. Dengan demikian dapat disimpulkan bahwa gender diversity (GD) tidak berpengaruh signifikan terhadap pengungkapan corporate social responsibility (CSRD).

$$
\text { Gender diversity tidak }
$$

berpengaruh signifikan terhadap pengungkapan corporate social responsibility dapat diartikan dengan tanpa adanya keberadaan wanita dalam jajaran dewan, maka perusahaan tetap dapat berjalan dalam melaksanakan pengawasan terhadap pengungkapan corporate social responsibility. Menurut Anjani (2009) dalam Solikhah dan Winarsih (2016) menyatakan bahwa di Indonesia menganut sistem kekerabatan patrilineal (garis keturunan ayah) dimana pria dianggap sebagai pemegang kontrol dan pengambil keputusan utama.

Hasil penelitian ini sejalan dengan penelitian yang dilakukan oleh Solikhah dan Winarsih (2016), Majeed et al (2015), Prasetianti (2014), Kahreh et al (2014) Kristi (2012) yang menyatakan bahwa gender diversity tidak berpengaruh signifikan terhadap pengungkapan corporate social responsibility. Namun penelitian ini tidak sejalan dengan penelitian yang dilakukan oleh Pratiwi et al (2018) yang menyatakan bahwa gender diversity memiliki pengaruh yang negatif signifikan terhadap pengungkapan corporate social responsibility, serta Fauziah (2018), Hadya dan Susanto (2018), Isa dan Muhammad, S (2015), Rahindayanti et al (2015) yang menyatakan bahwa gender diversity memiliki pengaruh yang posiif signifikan terhadap pengungkapan corporate social responsibility.

5. Pengaruh Media Exposure terhadap Pengungkapan Corporate Social Responsibility
Berdasarkan hasil uji hipotesis 5, menunjukkan bahwa variabel media exposure (ME) memiliki nilai probabilitas sebesar 0.3108. Hal ini menunjukkan bahwa nilai Prob. $>0,05$, maka $\mathrm{H}_{04}$ diterima dan $\mathrm{H}_{\mathrm{a} 4}$ ditolak. Dengan demikian dapat disimpulkan bahwa media exposure (ME) tidak berpengaruh signifikan terhadap pengungkapan corporate social responsibility (CSRD).

$$
\text { Media exposure tidak }
$$

berpengaruh signifikan terhadap pengungkapan corporate social responsibility. Hal ini dapat disebabkan oleh sampel penelitian yang masih memiliki keterbatasan dalam pengukuran media. Selain itu, perusahaan yang dijadikan sampel penelitian tidak semuanya mempublikasikan informasi mengenai kegiatan yang berkaitan dengan corporate social responsibility dalam media online (Kompas dan Republika). Menurut Solikhah dan Winarsih (2016) kecenderungan insan media dalam membuat liputan cenderung mempublikasikan isu-isu besar saja, karena anggapan bahwa isu-isu kecil kurang menjadi perhatian masyarakat. Menurut Widiastuti et al (2018) kemampuan jumlah publikasi oleh media online belum dapat mengukur media exposure.

Hasil penelitian ini sejalan dengan penelitian yang dilakukan oleh Widiastuti et al (2018), Solikhah dan Winarsih (2016) yang menyatakan bahwa media exposure tidak berpengaruh signifikan terhadap pengungkapan corporate social responsibility. Namun penelitian ini tidak sejalan dengan penelitian yang dilakukan oleh Alfarizi (2017), Tan et al (2016), Kristi (2012) yang menyatakan bahwa media exposure memiliki pengaruh yang positif signifikan terhadap pengungkapan corporate social responsibility. 


\section{Simpulan dan Saran}

\section{Simpulan}

1. Berdasarkan uji hipotesis 1, menunjukkan bahwa variabel board size, ownership diffusion, gender diversity dan media exposure secara simultan berpengaruh terhadap pengungkapan corporate social responsibility.

2. Berdasarkan uji hipotesis 2, board size memiliki arah negatif dan berpengaruh signifikan terhadap pengungkapan corporate social responsibility pada perusahaan indeks SRI-KEHATI yang terdaftar di Bursa Efek Indonesia (BEI) periode 2013-2017.

3. Berdasarkan uji hipotesis 3, ownership diffusion memiliki arah negatif dan tidak berpengaruh signifikan terhadap pengungkapan corporate social responsibility pada perusahaan indeks SRI-KEHATI yang terdaftar di Bursa Efek Indonesia (BEI) periode 20132017.

4. Berdasarkan uji hipotesis 4, gender diversity memiliki arah negatif dan tidak berpengaruh signifikan terhadap pengungkapan corporate social responsibility pada perusahaan indeks SRI-KEHATI yang terdaftar di Bursa Efek Indonesia (BEI) periode 20132017.

5. Berdasarkan uji hipotesis 5, media exposure memiliki arah negatif dan tidak berpengaruh signifikan terhadap pengungkapan corporate social responsibility pada perusahaan indeks SRI-KEHATI yang terdaftar di Bursa Efek Indonesia (BEI) periode 20132017.

\section{Saran}

Berdasarkan hasil penelitian, peneliti mengungkapkan saran sebagai berikut:

\section{Saran Teoretis}

a. Bagi akademisi, hasil penelitian ini dapat dijadikan sebagai referensi untuk penelitian selanjutnya dan menambah pengetahuan dalam menganalisis faktor-faktor yang mempengaruhi pengungkapan corporate social responsibility.

b. Bagi peneliti selanjutnya, diharapkan untuk menguji kembali variabelvariabel yang tidak berpengaruh dalam penelitian ini dan menambahkan variabel lainnya yang terkait dengan pengungkapan corporate social responsibility seperti kepemilikan saham manajerial, return on asset, dan ukuran perusahaan.

\section{Saran Praktis}

a. Penelitian ini menunjukkan bahwa board size memiliki pengaruh terhadap pengungkapan corporate social responsibility. Demikian perusahaan yang memiliki board size harus semakin meningkatkan kegiatan corporate social responsibility beserta pengungkapannya agar reputasi atau citra perusahaan semakin baik khususnya pada perusahaan indeks SRI-KEHATI yang terdaftar di Bursa Efek Indonesia (BEI), serta perusahaan diharapkan untuk meningkatkan pengungkapan CSR nya, terutama pada kategori lingkungan dan sosial (standar khusus), serta tata kelola (standar umum).

b. Bagi investor dan calon investor dalam pengambilan keputusan untuk penanaman modal ke suatu perusahaan khususnya perusahaan indeks SRI-KEHATI sebaiknya tidak hanya melihat laporan keuangannya saja, tetapi juga dari segi non keuangannya.

\section{Daftar Pustaka}

Abubakar, U. D., Hidayati, N., \& Mawardi, M. C. (2018). Pengaruh Good Corporate Governance dan Profitabilitas terhadap 
Pengungkapan Tanggung Jawab Sosial. E-JRA Vol. 07 No. 05.

Agoes, S., \& Ardana, I. C. (2014). Etika Bisnis dan Profesi. Jakarta: Salemba Empat.

Alfarizi, A. G. (2017). Pengaruh Media Exposure, Ukuran Perusahaan, Leverage dan Struktur Kepemilikan Saham terhadap Pengungkapan Corporate Social Responsibility. Universitas Muhammadiyah Yogyakarta.

Assegaf, Y., Falikhatun, \& Salamah Wahyuni. (2012). Bank Syariah Di Indonesia: Corporate Governance danPengungkapan

Pertanggungjawaban Sosial Islami . Bank Syariah Di Indonesia, Vol. 1 No. 1 December 2012 , 255-267.

Aziz, A. (2014). Analisis Pengaruh Good Corporate Governance (Gcg) Terhadap Kualitas Pengungkapan Sustainability Report. Jurnal Audit dan Akuntansi Fakultas Ekonomi Universitas Tanjungpura Vol.3, No. 2, 65-84.

Basuki, A., \& Prawoto, N. (2016). Analisis Regresi dalam Penelitian Ekonomi dan Bisnis: Diengkapi Aplikasi SPSS dan EViews. Depok: PT Rajagrafindo Persada.

Erviana, E., Afifudin, \& Junaidi. (2018). Analisis Pengaruh Leverage, Profitabiitas, Ukuran Perusahaan, dan Kepemilikan Saham Publik terhadap Kebijakan Pengungkapan Tanggungjawab Sosial dan Lingkungan pada Perusahaan Manufaktur di Bursa Efek Indonesia Tahun 2013-2016. Jurnal Ekonomi Universitas Islam Malang.

Fauziah, F. E. (2018). Diversitas Gender dan Nilai Perusahaan dengan Corporate Social Responsibility sebagai Variabel Intervening. Media Ekonomi dan Manajemen, 187-204.

Fitri, G. (2013). Pengaruh Good Corporate Governance terhadap Pengungkapan Corporate Social Responsibility pada Perusahaan Yang Terdaftar di Bursa Efek Indonesia . Jurnal Imiah Mahasiswa Fakultas Ekonomi dan Bisnis Universitas Brawijaya.

Global Reporting Initiative (GRI). (2013). G4-Pedoman Pelaporan Keberlanjutan. Tersedia: https://www.globalreporting.org/reso urcelibrary/Bahasa-Indonesia-G4Part-One.pdf.

Hadi, N. (2011). Corporate Social Responsibility edisi Pertama. Yogyakarta: Graha Ilmu.

Hadya, R., \& Susanto, R. (2018). Model Hubungan antara Keberagaman Gender, Pendidikan dan Nationality Dewan Komisaris terhadap Pengungkapan Corporate Social Responsibility. Jurnal Benefita 3(2) Juli 2018 , 149-160.

Isa, M., \& Muhammad, S. (2015). The Impact of Board Characteristics on Corporate Social Responsibility Disclosure: Evidence from Nigerian Food Product Firms. International Journal of Management Science and Business Administration, l(12), 3445.

Kahreh, M., Babania, A., Tive, M., \& Mirmehdi, S. (2014). An examination to effect of Gender Differences on the Corporate Social Responsibility (CSR). ProcediaSocial and Behavioral Sciences 109, 664-668.

Kristi, A. (2012). Faktor-faktor yang mempengaruhi pengungkapan Corporate Social Responsibility pada perusahaan publik di Indonesia. Universitas Brawijaya.

Liao, L., L, L., \& Q. Tang. (2015). Gender Diversity, Board Independences, Environmental Comittee, and Greenhouse Gas Disclosure. The British Accounting Review, 47 (4), 409-424.

Majeed, S., Aziz, T., \& Saleem, S. (2015). The Effect of Corporate Governance Elemnets on Corporate Social 
Responsibility (CSR) Disclosur: An Empirical Evidance from Listed Companies at KSE Pakistan. International Journal of Financial Studies ISSN 2227-7072, 530-556.

Ningrum, A. P. (2015). Pengaruh Tata Kelola Korporat Terhadap Pengungkapan Laporan Keberlanjutan.

Nur, M., \& Priantinah, D. (2012). Analisis Faktor-Faktor yang mempengaruhi Pengungkapan Corporate Social Responsibility di Indonesia (Studi Empiris pada Perusahaan Berkategori High Profile yang Listing di Bursa Efek Indonesia). Jurnal Nominal, Vol. 1, No. 1.

Prasetianti, N. (2014). Pengaruh Media dan Struktur Corporate Governance terhadap Kualitas Environmental Disclosure.

Pratiwi, M., \& Palupi, A. (2012). Analisis Pengaruh Ukuran Perusahaan, Kualitas Audit, Umur Perusahaan, Difusi Kepemilikan, Profitabilitas, Leverage, dan Tingkat Pertumbuhan terhadap Tingkat Pengungkapan Segmen Operasi. Jurnal Akuntansi Universitas Bakrie.

Rahindayanti, N. M., Ramantha, I. W., \& Rasmin, N. K. (2015). Pengaruh Diversitas Pengurus pada Luas Pengungkapan Corporate Social Responsibility Perusahaan Sektor Keuangan. E-Jurnal Ekonomi dan Bisnis Universitas Udayana 4.05, 312-330.

Restu, M., Yuliandari, W. S., \& Nurbaiti, A. (2017). Pengaruh Ukuran Dewan Komisaris, Proporsi Dewan Komisaris Independen dan Ukuran Komite Audit terhadap Pengungkapan Corporate Social Responsibility. e-Proceeding of Management : Vol.4, No.3 Desember 2017, 2742.

Rifqiyah, R. F. (2016). Pengaruh Kepemilikan Saham Publik, Profitabilitas, dan Media Terhadap
Pengungkapan Tanggung Jawab Sosial. Accounting Analysis Journal, ISSN 2252-6765.

Solikhah, B., \& Winarsih, A. M. (2016). Pengaruh Liputan Media, Kepekaan Industri, dan Struktur Tata Kelola Perusahaan Terhadap Kualitas Pengungkapan Lingkungan. Jurnal Akuntansi dan Keuangan Indonesia Vol. 13, 1-22.

Sugiyono. (2016). Metode Penelitian Kuantitatif, Kualitatif dan $R \& D$. Bandung: PT Alfabet.

Tan, A., Benni, D., \& Liani, W. (2016). Determinants of Corporate Social Responsibility Disclosure and Investor Reaction. International Journal of Economics and Financial Issues, 6(S4) , 11-17.

Umar, M. (2015). The Impact of Ownership and Board Structure on Corporate Social Responsibility (CSR) Reporting in the Turkish Banking Industry. Emerald Insight, Vol. 15, 357-374.

Widiastuti, H., Utami, E. R., \& Handoko, R. (2018). Pengaruh Ukuran Perusahaan, Tipe Industri, Growth, dan Media Exposure terhadap Pengungkapan Tanggung Jawab Sosial Perusahaan. Widiastuti, Utami, Handoko.

Wulolo, C. F.,\& Rahmawati, I.P.(2017). Analisis Pengungkapan Corporate Social Responsibility berdasarkan Global Reporting Initiative G4. Jurnal Organisasi dan Manajemen, Volume 13, Nomor 1, Maret 2017, 53-60

Yumna, N. W. (2018). Pengaruh Gender Diversity, Komisaris Independen, Kinerja Keuangan, Struktur Kepemilikan dan Kebijakan Hutang terhadap Nilai Perusahaan. Jurusan Akuntansi, Fakutas Ekonomi dan Bisnis. 